\section{Trumpetcreeper Control with Various Indole-3-Acetic Acid Mimics and Diflufenzopyr}

\author{
Joseph E. Beeler, Gregory R. Armel, James T. Brosnan ${ }^{1}$, \\ Jose J. Vargas, William E. Klingeman, Rebecca M. Koepke-Hill, \\ Gary E. Bates, Dean A. Kopsell, and Phillip C. Flanagan
}

\begin{abstract}
AdDITIONAL INDEX WORDs. aminocyclopyrachlor, aminopyralid, auxin mimic herbicides, dicamba, non-cropland, nursery crops, phytotoxicity, triclopyr, Campsis radicans, 2,4-D
\end{abstract}

Summary. Trumpetcreeper (Campsis radicans) is a native, perennial, weedy vine of pastures, row crops, fence rows, and right-of-ways throughout most of the eastern United States. Field and greenhouse studies were conducted in 2008 and 2009 near Newport, TN, and in Knoxville, TN, to evaluate aminocyclopyrachlormethyl and aminopyralid alone and in mixtures with 2,4-D and diflufenzopyr for selective trumpetcreeper control when applied postemergence in an abandoned nursery. These treatments were compared with commercial standards of dicamba and a prepackaged mixture of triclopyr plus 2,4-D. In the field, aminocyclopyrachlor-methyl alone controlled trumpetcreeper $77 \%$ to $93 \%$, while aminopyralid alone only controlled trumpetcreeper $0 \%$ to $20 \%$ by 12 months after treatment (MAT). The addition of diflufenzopyr or 2,4-D to aminocyclopyrachlor-methyl did not improve trumpetcreeper control in the field; however, the addition of 2,4-D to aminopyralid improved control of trumpetcreeper from $50 \%$ to $58 \%$. All aminocyclopyrachlor-methyl treatments controlled trumpetcreeper greater than or equal to dicamba and the prepackaged mixture of triclopyr plus 2,4-D. In the greenhouse, aminocyclopyrachlor and aminocyclopyrachlor-methyl applied at 8.75 to $35 \mathrm{~g} \cdot \mathrm{ha}^{-1}$ controlled trumpetcreeper $58 \%$ to $72 \%$ by 1 MAT. When both herbicides were applied at $70 \mathrm{~g} \cdot \mathrm{ha}^{-1}$, aminocyclopyrachlor controlled trumpetcreeper $64 \%$, while aminocyclopyrachlor-methyl controlled trumpetcreeper $99 \%$, similar to dicamba.

$\mathrm{T}$ rumpetcreeper is a native, perennial, weedy vine of pastures, row crops, fence rows, and right-of-ways throughout most of the eastern United States. This vine has the potential to cause significant interference in cultivated fields with fine textured soils (Elmore et al., 1989). Trumpetcreeper is highly competitive and is capable of growing several meters in length across the span of a single growing season (Elmore, 1984). Plants germinate from papery-textured, winged seeds that are $\approx 15 \mathrm{~mm}$ long and are contained in pods (Bryson and DeFelice, 2009). Chachalis and Reddy (2000) determined that there are about 20 to 40 pods produced on each individual trumpetcreeper plant

Plant Sciences Department, The University of Tennessee, 2431 Joe Johnson Drive, 252 Ellington Plant Sciences Building, Knoxville, TN 37996

The authors would like to thank Jake Huffer, David McIntosh, Bryan Guggan, and Joshua Williamson for their assistance on this project. In addition, the authors thank DuPont Crop Protection, BASF Corporation, and Dow AgroSciences for supplying the commercially available herbicides. Finally the authors thank Ed Kinsey of Kinsey Gardens for his guidance, generosity, and assistance with the field studies.

${ }^{1}$ Corresponding author. E-mail: jbrosnan@utk.edu. with each pod containing $\approx 700$ seeds. These researchers also determined that trumpetcreeper seed laying on the soil surface germinated about $68 \%$ but these same seeds would not germinate when incorporated $4 \mathrm{~cm}$ deep in the soil. Regardless, once established in an area trumpetcreeper primarily propagates and spreads from rhizomes (Bryson and DeFelice, 2009; Elmore et al., 1989). Trumpetcreeper is listed by Webster and Nichols (2012) as one of the most troublesome weeds in corn (Zea mays), cotton (Gossypium hirsutum), and soybean (Glycine max) in the midsouthern United States. It has been reported that just one plant per $0.5 \mathrm{~m}^{2}$ can reduce soybean yield by 18\% (Edwards and Oliver, 2001).

Once established in an area, trumpetcreeper control is difficult with nonchemical weed management tools. In fact, various methods of deep tillage and other forms of soil cultivation have proven inadequate. Edwards and Oliver (2004) found that both deep placement $(23 \mathrm{~cm})$ of trumpetcreeper rhizomes and reducing rhizome size delayed shoot emergence but did not affect shoot growth after emergence. In soybean, evaluations of deep tillage $(\approx 45 \mathrm{~cm})$ did not reduce trumpetcreeper densities the following year (Reddy, 2005).

Herbicides have been the primary tool for controlling trumpetcreeper; however, the results of their use have been variable. Contact herbicides like glufosinate have provided only aboveground control of trumpetcreeper with little or no effect on rhizomes (Reddy and Chachalis, 2004). Additional studies have examined the use of the systemic herbicide glyphosate for control of trumpetcreeper (Boyette et al., 2008; Bradley et al., 2004; DeFelice and Oliver, 1980; Edwards and Oliver, 2001; Reddy, 2005; Reddy and Chachalis, 2004). However, well-established stands of trumpetcreeper often have extensive rhizome mass which dilutes absorbed systemic herbicides like glyphosate. This morphology hampers herbicide accumulation within rhizomes at sufficient concentrations to prevent reinfestation (Reddy, 2005; Reddy and Chachalis, 2004). One study found that an early postemergence application of glyphosate $\left(1.26 \mathrm{~kg} \cdot \mathrm{ha}^{-1}\right)$ followed by a late postemergence application of glyphosate $\left(1.26 \mathrm{~kg} \cdot \mathrm{ha}^{-1}\right)$ reduced trumpetcreeper from 2.7 to 0.9 stems $/ \mathrm{m}^{2}$ following three consecutive years of this treatment regime (Reddy, 2005). A recent study found a synergistic interaction between mixtures

\begin{tabular}{llll}
\hline $\begin{array}{l}\text { Units } \\
\text { To convert U.S. to SI, } \\
\text { multiply by }\end{array}$ & U.S. unit & SI unit & $\begin{array}{l}\text { To convert SI to U.S., } \\
\text { multiply by }\end{array}$ \\
\hline 0.0929 & $\mathrm{ft}^{2}$ & $\mathrm{~m}^{2}$ & 10.7639 \\
9.3540 & gal/acre & $\mathrm{L} \cdot \mathrm{ha}^{-1}$ & 0.1069 \\
2.54 & inch $(\mathrm{es})$ & $\mathrm{cm}$ & 0.3937 \\
25.4 & inch $(\mathrm{es})$ & $\mathrm{mm}$ & 0.0394 \\
1.1209 & $\mathrm{lb} / \mathrm{acre}$ & $\mathrm{kg} \cdot \mathrm{ha}^{-1}$ & 0.8922 \\
28.3495 & $\mathrm{oz}$ & $\mathrm{g}$ & 0.0353 \\
70.0532 & $\mathrm{oz} / \mathrm{acre}$ & $\mathrm{g} \cdot \mathrm{ha}^{-1}$ & 0.0143 \\
6.8948 & $\mathrm{psi}$ & $\mathrm{kPa}$ & 0.1450 \\
$\left({ }^{\circ} \mathrm{F}-32\right) \div 1.8$ & ${ }^{\circ} \mathrm{F}$ & ${ }^{\circ} \mathrm{C}$ & $\left({ }^{\circ} \mathrm{C} \times 1.8\right)+32$
\end{tabular}


of glyphosate and the bioherbicide Myrothecium verucaria; this combination provided $90 \%$ control of trumpetcreeper at $12 \mathrm{~d}$ after treatment while glyphosate (1.12 kg.ha ${ }^{-1}$ acid equivalent) or Myrothecium verucaria alone controlled trumpetcreeper $45 \%$ and $30 \%$, respectively (Boyette et al., 2008). Bradley et al. (2003) reported that reduced rates of two mimics of indole-3acetic acid, dicamba $\left(280 \mathrm{~g} \cdot \mathrm{ha}^{-1}\right)$ and 2,4-D (280 g.ha $\left.{ }^{-1}\right)$, controlled trumpetcreeper $65 \%$ and $69 \%$, respectively when applied in corn. However, in non-crop areas where crop competition with trumpetcreeper is not involved, greater rates of a prepackaged mixture of two mimics of indole-3-acetic acid (i.e., triclopyr plus 2,4-D) applied at 3360 to $5040 \mathrm{~g} \cdot \mathrm{ha}^{-1}$ was required to provide $60 \%$ to $79 \%$ trumpetcreeper control (Nice et al., 2006). Therefore, while older chemicals that mimic indole-3acetic acid can suppress trumpetcreeper, it is important to evaluate new, more potent chemistries that target this mode of action for trumpetcreeper control.

Aminocyclopyrachlor and aminopyralid are recently registered mimics of indole-3-acetic acid (Herbicide Resistance Action Committee Group O) that are used for control of perennial broadleaf plants in non-crop areas (Koepke-Hill et al., 2011; Senseman, 2007). Aminocyclopyrachlor has been evaluated in both its free acid and methyl ester forms, while aminopyralid has been primarily evaluated in its free acid form (Senseman, 2007; Turner et al., 2009). Both herbicides are systemic and readily absorbed through leaves and roots of susceptible plants (Bukun et al., 2010; Senseman, 2007). Several perennial weeds species have been controlled by each of these herbicides applied between 60 and $280 \mathrm{~g} \cdot \mathrm{ha}^{-1}$ (Enloe and Kniss, 2009; Ferrell et al., 2006; Koepke-Hill et al., 2011; Westra et al., 2008). In addition, each of these materials can often be applied in mixtures with other herbicides to broaden the spectrum of weeds controlled by a single application (Senseman, 2007; Turner et al., 2009). However, there have been no published reports to date on trumpetcreeper control with aminocyclopyrachlor or aminopyralid applied alone or in mixtures with other common herbicides.

The primary objective of this research was to evaluate aminocyclopyrachlormethyl and aminopyralid alone and in mixtures with another mimic of indole-3-acetic acid (i.e., 2,4-D) and the auxin transport inhibitor diflufenzopyr for control of trumpetcreeper in the field compared with commercial standards of dicamba and a prepackaged mixture of triclopyr plus 2,4-D. A secondary objective was to evaluate reduced rates of aminocyclopyrachlor in both the free acid and methyl ester form with and without 2,4-D compared with the commercial standard dicamba for control of trumpetcreeper in a greenhouse controlled environment.

\section{Materials and methods}

Field study. Field studies were initiated at two adjacent sites in 2008 in an abandoned nursery near Newport, TN. These sites had been abandoned because of the aggressive competition of trumpetcreeper vine with previously planted nursery stock. Both study locations contained a Waynesboro loam soil (clayey, kaolinitic, thermic typic paleudults). Treatments were applied on $10 \times 25$-ft plots arranged in a randomized complete block design (RCBD), with three replications, in areas already infested with trumpetcreeper. Herbicide treatments were applied postemergence with a carbon dioxide $\left(\mathrm{CO}_{2}\right)$ powered backpack sprayer calibrated to deliver 23 gal/acre at $60 \mathrm{psi}$. The spray boom contained four flat fan nozzles (Teejet 8002 flat fan nozzle; Spraying Systems, Wheaton, IL) spaced 18 inches apart. The spray swath was $8.5 \mathrm{ft}$ with the boom positioned at a height of 18 inches above the trumpetcreeper plants. Applications were made on 11 July 2008 for study 1 and 25 July 2008 for study 2 to trumpetcreeper 9.5 inches in height.

Herbicide treatments included aminocyclopyrachlor-methyl (DuPont Crop Protection, Wilmington, DE) at 70,140 , and $280 \mathrm{~g} \cdot \mathrm{ha}^{-1}$, aminocyclopyrachlor (free carboxylic acid, DuPont Crop Protection) at 70, 140, and $280 \mathrm{~g} \cdot \mathrm{ha}^{-1}$, aminopyralid (Milestone ${ }^{\circledR}$; Dow AgroSciences, Indianapolis, IN) at 70 and $140 \mathrm{~g} \cdot \mathrm{ha}^{-1}, 2,4-\mathrm{D}$ (Weedone ${ }^{\circledR}$ LV4 EC; Nufarm, Burr Ridge, IL) at $1080 \mathrm{~g} \cdot \mathrm{ha}^{-1}$, and diflufenzopyr (25\% WP, DuPont Crop Protection) at $70 \mathrm{~g} \cdot \mathrm{ha}^{-1}$. Also included as treatments were the mixtures of aminocyclopyrachlor-methyl at $70 \mathrm{~g} \cdot \mathrm{ha}^{-1}$ plus 2,4-D at $1080 \mathrm{~g} \cdot \mathrm{ha}^{-1}$, aminopyralid at $140 \mathrm{~g} \cdot \mathrm{ha}^{-1}$ plus $2,4-\mathrm{D}$ at $1080 \mathrm{~g} \cdot \mathrm{ha}^{-1}$, aminocyclopyrachlor-methyl at $70 \mathrm{~g} \cdot \mathrm{ha}^{-1}$ plus diflufenzopyr at $70 \mathrm{~g} \cdot \mathrm{ha}^{-1}$, and aminopyralid at $140 \mathrm{~g} \cdot \mathrm{ha}^{-1}$ plus diflufenzopyr at $70 \mathrm{~g} \cdot \mathrm{ha}^{-1}$. These treatments were compared with the commercial standards dicamba (Clarity ${ }^{\circledR}$; BASF, Research Triangle Park, NC) at $2240 \mathrm{~g} \cdot \mathrm{ha}^{-1}$ and a prepackaged mixture of triclopyr plus 2,4-D (Crossbow ${ }^{\circledR}$, Dow AgroSciences) at $2242 \mathrm{~g} \cdot \mathrm{ha}^{-1}$ plus $4483 \mathrm{~g} \cdot \mathrm{ha}^{-1}$, respectively. All treatments in these field studies included a methylated seed oil surfactant (Universal Crop Protection Alliance, Eagan, $\mathrm{MN}$ ) at $1 \% \mathrm{v} / \mathrm{v}$.

Trumpetcreeper control was visually rated on a $0 \%$ (no injury) to $100 \%$ (complete kill) scale at 2 and 12 MAT. Trumpetcreeper stem density and length were recorded from two randomly positioned $0.25-\mathrm{m}^{2}$ areas within in each plot at 12 MAT. All trumpetcreeper vines present in each $0.25-\mathrm{m}^{2}$ area were counted and lengths were recorded. After this data had been collected, trumpetcreeper harvested from each $0.25-\mathrm{m}^{2}$ area was dried at $134^{\circ} \mathrm{F}$ for $72 \mathrm{~h}$. Aboveground biomass values were then recorded for each sample.

GreENHOUSE STUDY. Greenhouse studies were initiated in 2009 in Knoxville, TN, to confirm visual observations from the aforementioned field studies. Trumpetcreeper stems (4 inches long, two mature leaves) were harvested from the field sites, dipped in a solution of indole-3-butryic acid (Hormodin \# 1 ; OHP, Mainland, $\mathrm{PA}$ ), and maintained under mist for 2 months. Rooted plants were transplanted into $9.5 \times 9.5-\mathrm{cm}$ pots (Dillen 4 " traditional greenhouse pots; Myers Industry, Sparks, NV) filled with a Sequatchie loam soil (fine-loamy, siliceous, semiactive, thermic humic Hapludult) blended in a 3:1 ratio with a clay mineral soil amendment (Turface; Profile Products, Buffalo Grove, IL). Plants were allowed to acclimate to greenhouse conditions during which time they were fertilized (Plantex 20N-20P-20K water soluble fertilizer; Plant Products, Brampton, ON, Canada) and watered when needed to maximize growth and vigor. Treatments in greenhouse studies were arranged in a RCBD with three replications and repeated in time during 2009.

Herbicide treatments were applied plants with at least two shoots measuring between 24 and 36 inches in length. Herbicides included: aminocyclopyrachlormethyl at $8.75,17.5,35$, and $70 \mathrm{~g} \cdot \mathrm{ha}^{-1}$, 
aminocyclopyrachlor at $8.75,17.5$, 35 , and $70 \mathrm{~g} \cdot \mathrm{ha}^{-1}, 2,4-\mathrm{D}$ at 135,270 , and $540 \mathrm{~g} \cdot \mathrm{ha}^{-1}$, and dicamba at 1919 $\mathrm{g} \cdot \mathrm{ha}^{-1}$. Also included were the following tank mixture treatments: 1) aminocyclopyrachlor-methyl at 8.75 $\mathrm{g} \cdot \mathrm{ha}^{-1}$ plus $2,4-\mathrm{D}$ at $135 \mathrm{~g} \cdot \mathrm{ha}^{-1}, 2$ ) aminocyclopyrachlor-methyl at 17.5 $\mathrm{g} \cdot \mathrm{ha}^{-1}$ plus 2,4-D at $270 \mathrm{~g} \cdot \mathrm{ha}^{-1}, 3$ ) aminocyclopyrachlor-methyl at 35 $\mathrm{g} \cdot \mathrm{ha}^{-1}$ plus 2,4-D at $\left.540 \mathrm{~g} \cdot \mathrm{ha}^{-1}, 4\right)$ aminocyclopyrachlor at $8.75 \mathrm{~g} \cdot \mathrm{ha}^{-1}$ plus 2,4-D at $135 \mathrm{~g} \cdot \mathrm{ha}^{-1}, 5$ ) aminocyclopyrachlor at $17.5 \mathrm{~g} \cdot \mathrm{ha}^{-1}$ plus $2,4-\mathrm{D}$ at $270 \mathrm{~g} \cdot \mathrm{ha}^{-1}$, and 6) aminocyclopyrachlor at $35 \mathrm{~g} \cdot \mathrm{ha}^{-1}$ plus $2,4-\mathrm{D}$ at $540 \mathrm{~g} \cdot \mathrm{ha}^{-1}$. Aminocyclopyrachlor and aminocyclopyrachlor-methyl rates in the greenhouse studies were lower than those evaluated in the field to evaluate potential synergy of 2,4-D tank mixtures for trumpetcreeper control. All treatments in the greenhouse studies included a methylated seed oil surfactant at $1 \% \mathrm{v} / \mathrm{v}$. Treatments were applied postemergence with a $\mathrm{CO}_{2}$ powered backpack sprayer calibrated to deliver $23 \mathrm{gal} /$ acre at 40 psi through flat fan nozzles at a height of 30 inches above the plant canopy. All greenhouse applications were made on 18 Apr. 2009.

Trumpetcreeper control was rated visually on a $0 \%$ (no injury) to
$100 \%$ (complete kill) scale at 1 MAT. Plants were harvested following the 1 MAT visual evaluation and plant fresh weight (FW) biomass was recorded.

Statistical analysis. Data for all studies were arcsine transformed before being subjected to analysis of variance in SAS (version 9.1.3; SAS Institute, Cary, NC), with main effects and all possible interactions tested using the appropriate expected mean square values described by McIntosh (1983). Interpretations were not different from non-transformed data; therefore, non-transformed means are presented for clarity. Fisher's protected least significant difference test was used for mean separation at the $P<0.05$ level. Data were pooled over studies when no treatment-by-study interaction occurred.

\section{Results and discussion}

Field study. No treatment-bystudy interactions occurred for stem length or density measurements; therefore, these data were pooled over studies (Table 1). All other data from the field studies are presented individually. Aminocyclopyrachlor-methyl alone or in combination with 2,4-D or diflufenzopyr provided at least $90 \%$ control of trumpetcreeper in both studies by 2 MAT (Table 1 ). The herbicidal response observed in our studies was similar to other research describing aminocyclopyrachlor or aminocyclopyrachlor-methyl activity on other herbaceous perennial weeds (Koepke-Hill et al., 2011; Westra et al., 2008). In contrast, aminopyralid alone did not provide greater than $37 \%$ control of trumpetcreeper by 2 MAT. The addition of $2,4-\mathrm{D}$ to aminocyclopyrachlor-methyl did not improve trumpetcreeper control because aminocyclopyrachlor-methyl alone provided $>90 \%$ control; however, the addition of 2,4-D to aminopyralid provided improved trumpetcreeper control to $93 \%$ by 2 MAT. The addition of diflufenzopyr did not improve trumpetcreeper control when applied in combinations with aminocyclopyrachlor-methyl or aminopyralid. Similarly, other researchers have noted a differential response from combinations of diflufenzopyr with various mimics of indole-3-acetic acid (Enloe and Kniss, 2009). Both dicamba and the prepackaged mixture of triclopyr and 2,4-D provided $86 \%$ to $97 \%$ control of trumpetcreeper vine by 2 MAT.

By 12 MAT, all aminocyclopyrachlor-methyl treatments controlled trumpetcreeper $77 \%$ to $93 \%$, while all aminopyralid treatments provided less than $59 \%$ control (Table 1). Dicamba,

Table 1. Trumpetcreeper control, biomass, stem length, and stem density following postemergence applications of several mimics of indole-3-acetic acid and diflufenzopyr during two field studies conducted on an abandoned nursery outside of Newport, TN, during 2008. Biomass, stem length, and stem density data were collected 12 mo. after treatment (MAT). No year by treatment interaction occurred for stem length and stand density; therefore, these data are pooled over studies.

\begin{tabular}{|c|c|c|c|c|c|c|c|c|c|}
\hline \multirow[b]{3}{*}{ Treatments $^{\mathrm{z}}$} & \multirow[b]{3}{*}{ Rate $\left(\mathrm{g} \cdot \mathrm{ha} \mathrm{a}^{-1}\right)^{\mathrm{y}}$} & \multicolumn{6}{|c|}{ Trumpetcreeper control } & \multirow{3}{*}{$\begin{array}{c}\text { Stem } \\
\text { length } \\
(\mathrm{cm})^{\mathrm{y}}\end{array}$} & \multirow{3}{*}{$\begin{array}{c}\text { Stem } \\
\text { density } \\
\left(\text { stems } / \mathrm{m}^{2}\right)^{\mathrm{y}}\end{array}$} \\
\hline & & \multicolumn{2}{|c|}{2 MAT (\%) } & \multicolumn{2}{|c|}{12 MAT (\%) } & \multicolumn{2}{|c|}{ Biomass $(\mathrm{g})^{\mathrm{y}}$} & & \\
\hline & & Study 1 & Study 2 & Study 1 & Study 2 & Study 1 & Study 2 & & \\
\hline Aminocyclopyrachlor-methyl & 70 & 94 & 90 & 77 & 87 & 3 & 1 & 31 & 2 \\
\hline Aminocyclopyrachlor-methyl & 140 & 96 & 96 & 77 & 82 & 0 & 0 & 0 & 0 \\
\hline Aminocyclopyrachlor-methyl & 280 & 98 & 99 & 77 & 93 & 9 & 0 & 31 & 4 \\
\hline Aminopyralid & 70 & 27 & 28 & 0 & 3 & 132 & 29 & 173 & 8 \\
\hline Aminopyralid & 140 & 30 & 37 & 20 & 18 & 57 & 32 & 109 & 8 \\
\hline $2,4-\mathrm{D}$ & 1080 & 95 & 87 & 45 & 54 & 0 & 7 & 18 & 1 \\
\hline Diflufenzopyr & 70 & 25 & 3 & 0 & 0 & 96 & 72 & 160 & 20 \\
\hline $\begin{array}{l}\text { Aminocyclopyrachlor-methyl } \\
\quad+2,4-\mathrm{D}\end{array}$ & $70+1080$ & 98 & 95 & 82 & 87 & 0 & 1 & 5 & 1 \\
\hline Aminopyralid + 2,4-D & $70+1080$ & 93 & 93 & 58 & 50 & 5 & 0 & 46 & 4 \\
\hline $\begin{array}{l}\text { Aminocyclopyrachlor-methyl } \\
+ \text { diflufenzopyr }\end{array}$ & $70+70$ & 99 & 94 & 77 & 87 & 0 & 0 & 0 & 0 \\
\hline Aminopyralid + diflufenzopyr & $70+70$ & 25 & 35 & 10 & 15 & 42 & 99 & 188 & 12 \\
\hline Triclopyr + 2,4-D & $2242+4483$ & 87 & 95 & 35 & 72 & 35 & 3 & 81 & 4 \\
\hline Dicamba & 2240 & 86 & 97 & 53 & 83 & 4 & 0 & 28 & 4 \\
\hline Untreated control & - & 0 & 0 & 0 & 0 & 54 & 103 & 127 & 16 \\
\hline $\operatorname{LSD}_{0.05^{x}}$ & & 10 & 9 & 16 & 13 & 70 & 31 & 71 & 8 \\
\hline
\end{tabular}

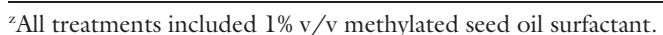

${ }^{\mathrm{y}} \mathrm{l} \mathrm{g} \cdot \mathrm{ha}^{-1}=0.0143 \mathrm{oz} /$ acre, $\mathrm{l} \mathrm{g}=0.0353 \mathrm{oz}, \mathrm{l} \mathrm{cm}=0.3937 \mathrm{inch}, \mathrm{l}$ stem $/ \mathrm{m}^{2}=0.0929 \mathrm{stem} / \mathrm{ft}^{2}$.

x Least significant difference at $P=0.05$. 
2,4-D, and the prepackaged mixture of triclopyr plus $2,4-\mathrm{D}$ provided variable control of trumpetcreeper vine (35\% to $83 \%$ ) over studies by 12 MAT. Dicamba and 2,4-D alone, aminopyralid plus 2,4-D, and all rates and mixtures of aminocyclopyrachlor-methyl were the only treatments that reduced both stem length and density compared with the untreated control. Similarly, these same treatments held trumpetcreeper dry weight biomass to below $10 \mathrm{~g}$ per plot in both field studies, while the untreated control contained 54 to $103 \mathrm{~g}$ of trumpetcreeper dry weight biomass.

Greenhouse study. No studyby-treatment interaction occurred for trumpetcreeper control or FW biomass data; therefore, these data were pooled over studies (Table 2 ). By 1 MAT, aminocyclopyrachlor or aminocyclopyrachlor-methyl alone at 8.75 and $35 \mathrm{~g} \cdot \mathrm{ha}^{-1}$ controlled trumpetcreeper $58 \%$ to $72 \%$. However, at $70 \mathrm{~g} \cdot \mathrm{ha}^{-1}$ aminocyclopyrachlor provided $63 \%$ control of trumpetcreeper, while aminocyclopyrachlor-methyl controlled trumpetcreeper $99 \%$, similar to dicamba. Differences in efficacy with aminocyclopyrachlor and aminocyclopyrachlor-methyl in the greenhouse could potentially be related to the lipophilic nature of the methyl ester formulation allowing for greater absorption into trumpetcreeper foliage (Bukun et al., 2010). When aminocyclopyrachlor or aminocyclopyrachlormethyl was applied at 17.5 to $35 \mathrm{~g} \cdot \mathrm{ha}^{-1}$ with 2,4-D, trumpetcreeper was controlled $94 \%$ to $99 \%$. Applications of 2,4-D alone at 135 to $540 \mathrm{~g} \cdot \mathrm{ha}^{-1} \mathrm{con}-$ trolled trumpetcreeper $74 \%$ to $91 \%$. Treatment with dicamba (1919 g.ha $\left.{ }^{-1}\right)$, 2,4-D (540 g.ha $\left.{ }^{-1}\right)$, and tank mixtures of aminocyclopyrachlor or aminocyclopyrachlor-methyl applied at $35 \mathrm{~g} \cdot \mathrm{ha}^{-1}$ plus 2,4-D all reduced trumpetcreeper FW biomass in comparison with the untreated control. When applied alone aminocyclopyrachlor-methyl at 35 and $70 \mathrm{~g} \cdot \mathrm{ha}^{-1}$ also reduced trumpetcreeper FW biomass in comparison with the untreated control. However, aminocyclopyrachlor alone at the same rates did not reduce trumpetcreeper FW biomass.

In both the field and greenhouse studies, aminocyclopyrachlor-methyl provided excellent trumpetcreeper control while aminopyralid was ineffective.

Table 2. Trumpetcreeper control and fresh weight biomass following postemergence applications of aminocyclopyrachlor, aminocyclopyrachlormethyl, 2,4-D, and dicamba at 1 mo. after treatment. Data were collected during two greenhouse studies conducted in Knoxville, TN during 2009. No treatment-by-study interactions were detected; therefore, data from each study were pooled.

\begin{tabular}{|c|c|c|c|}
\hline Treatments $^{\mathrm{z}}$ & Rate $\left(\mathrm{g} \cdot \mathrm{ha} \mathrm{a}^{-1}\right)^{\mathrm{y}}$ & $\begin{array}{l}\text { Trumpetcreeper } \\
\text { control (\%) }\end{array}$ & $\begin{array}{c}\text { Fresh wt } \\
\text { biomass }(\mathrm{g})^{\mathrm{y}}\end{array}$ \\
\hline Aminocyclopyrachlor & 8.75 & 58 & 3.28 \\
\hline Aminocyclopyrachlor & 17.5 & 72 & 2.52 \\
\hline Aminocyclopyrachlor & 35 & 69 & 3.32 \\
\hline Aminocyclopyrachlor & 70 & 63 & 3.88 \\
\hline Aminocyclopyrachlor-methyl & 8.75 & 58 & 3.68 \\
\hline Aminocyclopyrachlor-methyl & 17.5 & 63 & 3.35 \\
\hline Aminocyclopyrachlor-methyl & 35 & 72 & 1.62 \\
\hline Aminocyclopyrachlor-methyl & 70 & 99 & 1.33 \\
\hline $2,4-\mathrm{D}$ & 135 & 74 & 2.57 \\
\hline $2,4-\mathrm{D}$ & 270 & 75 & 2.08 \\
\hline $2,4-\mathrm{D}$ & 540 & 91 & 1.38 \\
\hline Aminocyclopyrachlor $+2,4-\mathrm{D}$ & $8.75+135$ & 63 & 3.20 \\
\hline Aminocyclopyrachlor $+2,4-\mathrm{D}$ & $17.5+270$ & 94 & 1.25 \\
\hline Aminocyclopyrachlor + 2,4-D & $35+540$ & 95 & 1.48 \\
\hline Aminocyclopyrachlor-methyl $+2,4-\mathrm{D}$ & $8.75+135$ & 82 & 2.13 \\
\hline Aminocyclopyrachlor-methyl $+2,4-\mathrm{D}$ & $17.5+270$ & 99 & 0.47 \\
\hline Aminocyclopyrachlor-methyl $+2,4-\mathrm{D}$ & $35+540$ & 99 & 0.25 \\
\hline Dicamba & 1919 & 99 & 0.45 \\
\hline Untreated control & - & 0 & 3.80 \\
\hline $\operatorname{LSD}_{0.05}{ }^{\mathrm{x}}$ & & 13 & 1.75 \\
\hline
\end{tabular}

${ }^{\mathrm{z}}$ All treatments included $\mathrm{l} \% \mathrm{v} / \mathrm{v}$ methylated seed oil surfactant.

${ }^{\mathrm{y}} \mathrm{l} \mathrm{g} \cdot \mathrm{ha}^{-1}=0.0143 \mathrm{oz} / \mathrm{acre}, \mathrm{lg}=0.0353 \mathrm{oz}$.

x Least significant difference at $P=0.05$.

Aminocyclopyrachlor-methyl controlled trumpetcreeper greater than or equal to commercial standards of dicamba and the prepackaged mixture of triclopyr plus 2,4-D. The addition of 2,4-D or diflufenzopyr to aminocyclopyrachlormethyl did not improve control of trumpetcreeper in the field, but when aminocyclopyrachlor-methyl was applied at lower rates in the greenhouse environment there was an obvious increase in activity associated with these mixtures. When aminocyclopyrachlor and aminocyclopyrachlor-methyl were applied at $70 \mathrm{~g} \cdot \mathrm{ha}^{-1}$ in the greenhouse, aminocyclopyrachlor-methyl was more effective at controlling trumpetcreeper and reducing FW biomass. Results of these studies demonstrate that aminocyclopyrachlor-methyl has the potential to provide excellent control of trumpetcreeper in non-crop areas, especially as a part of a reclamation project in abandoned nursery fields. However, future research must be conducted to determine the number of applications needed to eradicate trumpetcreeper and what type of replanting restrictions would be required to safely re-establish nursery stock following these applications.

\section{Literature cited}

Boyette, C.D., R.E. Hoagland, M.A. Weaver, and K. Reddy. 2008. Redvine (Brunnichia ovata) and trumpetcreeper (Campsis radicans) controlled under field conditions by a synergistic interaction of the bioherbicide, Myrothescium verrucaria, with glyphosate. Weed Biol. Mgt. 8: $39-45$.

Bradley, K.W., E.S. Hagood, Jr., and P.H. Davis. 2003. Evaluation of postemergence herbicide combinations for longterm trumpetcreeper (Campsis radicans) control in corn (Zea mays). Weed Technol. 17:718-723.

Bradley, K.W., E.S. Hagood, Jr., and P.H. Davis. 2004. Trumpetcreeper (Campsis radicans) control in double-crop glyphosateresistant soybean with glyophosate and conventional herbicide systems. Weed Technol. 18:298-303.

Bryson, C.T. and M.S. DeFelice. 2009. Weeds of the South. University of Georgia Press, Athens, GA.

Bukun, B., R.B. Lindenmeyer, S.J. Nissen, P. Westra, D.L. Shaner, and G. Brunk. 2010. Absorption and translocation of aminocyclopyrachlor and aminocyclopyrachlormethyl ester in canada thistle (Cirsium arvense). Weed Sci. 58:96-102. 
Chachalis, D. and K.N. Reddy. 2000. Factors affecting Campsis radicans seed germination and seedling emergence. Weed Sci. 48:212-216.

DeFelice, M.S. and L.R. Oliver. 1980. Redvine and trumpetcreeper control in soybeans and grain sorghum. Arkansas Farm Res. 29:5.

Edwards, J.T. and L.R. Oliver. 2001. Interference and control of trumpetcreeper (Campsis radicans) in soybean. Weed Technol. 18:816-819.

Edwards, J.T. and L.R. Oliver. 2004. Emergence and growth of trumpetcreeper (Campsis radicans) as affected by rootstock size and planting depth. Proc. Southern Weed Sci. Soc. 54:130-131 (abstr.).

Elmore, C.D. 1984. Perennial vines in the Delta of Mississippi. Mississippi Agr. For. Expt. Sta. Bul. 927.

Elmore, C.D., L.G. Heatherly, and R.A. Wesley. 1989. Perennial vine control in multiple cropping systems on a clay soil. Weed Technol. 3:282-287.
Enloe, S.F. and A.R. Kniss. 2009. Influence of diflufenzopyr addition to picolinic acid herbicides for russian knapweed (Acroptilon repens) control. Weed Technol. 23:450-454.

Ferrell, J.A., J.J. Mullahey, K.A. Langeland, and W.N. Ki. 2006. Control of tropical soda apple (Solanum viarum) with aminopyralid. Weed Technol. 20:453-457.

Koepke-Hill, R.M., G.R. Armel, W.E Klingeman, M.A. Halcomb, J.J. Vargas, and P.C. Flanagan. 2011. Mugwort control in an abandoned nursery using herbicides that mimic indole-3-acetic acid. HortTechnology 21:558-562.

McIntosh, M.S. 1983. Analysis of combined experiments. Agron. J. 75:153-155.

Nice, G., B. Johnson, and T. Bauman. 2006. Trumpetcreeper control. 5 Mar. 2010. <www.btny.purdue/weedscience/ 2006/trumpetcreeper06.pdf>.

Reddy, K.N. 2005. Deep tillage and glyphosate-reduced redvine (Brunnichia ovata) and trumpetcreeper (Campsis radicans) populations in glyphosate-resistant soybean. Weed Technol. 19:713-718.
Reddy, K.N. and D. Chachalis. 2004. Redvine (Brunnichia ovata) and trumpet creeper (Campsis radicans) management in glufosinate- and glyphosate-resistant soybean. Weed Technol. 5:125-129.

Senseman, S.A. 2007. Herbicide handbook. 9th ed. Weed Sci. Soc. Amer., Lawrence, KS.

Turner, R.G., J.S. Claus, E. Hidalgo, M.J. Holliday, and G.R. Armel. 2009. Technical introduction of the new DuPont vegetation management herbicide aminocyclopyrachlor. Weed Sci. Soc. Amer. 49:405 (abstr.).

Webster, T.M. and R.L. Nichols. 2012. Changes in prevalence of weed species in major agronomic crops of the southern United States: 1994/1995-2008/2009. Weed Sci. 60:145-157.

Westra, P., S. Nissen, T. Gaines, B. Bekun, B. Lindenmayer, and D. Shaner. 2008. Aminocyclopyrachlor for invasive weed management and restoration grass safety in the central great plains. Proc. North Central Weed Sci. Soc. 63:203 (abstr.). 